RELATING TQM, MARKETING AND BUSINESS PERFORMANCE:

AN EXPLORATORY STUDY

Angel. R. Martinez-Lorente

Department of Economia de la Empresa, University of Murcia, Spain

Frank Dewhurst

Manchester School of Management, UMIST, Manchester, United Kingdom

Alejandrino Gallego-Rodriguez

Department of Economia de la Empresa, University of Murcia, Spain

Corresponding author:

Angel R. Martinez-Lorente, Escuela Universitaria de Estudios Empresariales, Paseo Alfonso XIII, 50, 30203, Cartagena, Spain, tel.: 68 325618, fax: 68 325435, e-mail: arml@plc.um.es. 


\title{
RELATING TQM, MARKETING AND BUSINESS PERFORMANCE: AN EXPLORATORY STUDY
}

\begin{abstract}
Total Quality Management (TQM) is perhaps the leading management approach that companies employ to improve their product and service quality with the aim of improving typical measures of business performance (e.g. increased profits, increased market share, reduced costs). However, consumer perception of quality not only results from an evaluation of the intrinsic quality attributes of the product (e.g. performance, reliability, durability) but is also affected by the marketing mix (e.g. price, advertising, warranties) adopted by the company selling the product.
\end{abstract}

This paper offers a first attempt at cross-functional fertilization by examining the relationships between TQM, some marketing mix variables and measures of company performance by exploring the diverse multi-disciplinary literature and developing an explanatory framework, which is tested using non-parametric correlation and refined through an empirical study of Spanish manufacturing companies.

The results show that the most important TQM dimensions are the system of employee relations and the use of quality management-related design tools. The results also indicate the existence of a relationship amongst price, advertising and warranties, but that these marketing variables were not related with TQM and that further research is required to include a wider definition of marketing strategy.

Key words: Total Quality Management, Marketing Mix, Business performance 


\section{Introduction}

Quality is regarded by most producers as one of the most important aspects of manufacturing, service and purchasing strategies. Several studies, for example, Aaker and Jacobson (1994), Anderson et al. (1994), Buzzell et al. (1975), Capon et al. (1990), Craig and Douglas (1982), Farris and Reibstein (1979), Jacobson and Aaker (1987), McGuire et al. (1990) and Phillips et al. (1983) have reported that perceived product quality is related to increased sales and profits and consumers make their purchase decisions in relation to perceived quality (Gale and Buzzell, 1989). But what is perceived product quality? According to Garvin (1988), it is one of eight dimensions that shape the quality concept, the others are: performance, features, reliability, conformance, durability, aesthetics and serviceability (the intrinsic attributes or physical characteristics of a product). Intrinsic attributes can be improved in two ways: offering improved performance, additional features, etc (which has a clear cost implication) and by applying Total Quality Management (TQM), which not only improves conformance levels but also has a positive impact on other quality dimensions (Flynn et al., 1995).

Feigenbaum (1983) and Ishikawa (1985) propose that TQM is the best approach to quality management and authors such as Crosby (1987) and Dale and Plunkett (1995) claim that TQM can lead not only to increases in quality but also to reductions in costs. Some studies, for example, American Quality Foundation (1991), Hendricks and Singhal (1996 and 1997), Kano et al. (1983), Larry (1993), National Institute of Standards and Technology (1998), US General Accounts Office (1991), and Wisner and Eakins (1994) have shown the existence of a positive relationship between TQM and company performance whilst, others, for example, Fisher (1992), Fuchsberg (1993a and 1993b), Mathews (1992) and Naj (1993) report TQM failures. However, these studies only 
considered relationships between TQM and company performance but not the contribution of individual TQM dimensions. Adam (1994), Adam et al. (1997), Anderson et al. (1995), Flynn et al. (1995), Forker (1997), Ittner and Larcker (1997) and Powell (1995) have considered how different quality improvement practices are related to company performance. However, there is a lack of agreement in the findings and some results are contradictory with TQM theories, as shown in Table 1 below.

\section{$<$ Take in Table 1 here $>$}

A full discussion of the dimensions constituting TQM that have appeared in the literature can be found in Martinez-Lorente et al. (1998a) whilst Martinez-Lorente et al. (1998b) present seven common dimensions for measuring TQM as shown in Table 2.

\section{<Take in Table 2 here $>$}

The intrinsic attributes of a product are not the only determinants of consumer demand (Kuehn and Day, 1962 and Zeithaml, 1988). Consumer quality perceptions are influenced by marketing mix variables (Boulding and Kirmani, 1993, Gotlied and Sarel, 1992, Zeithaml, 1988) and constitute one of the basic elements in the definition of a company marketing strategy. A marketing strategy requires decisions on the target market and the marketing mix (i.e. pricing, distribution, sales force, advertising and sales promotion, and product design) (Kotler, 1980).

Thus perceived quality results from consumers evaluation of intrinsic attributes and of their interpretation of extrinsic attributes (i.e. price, advertising, warranties, country of origin and store image) (Darby and Karni, 1973, Garvin, 1988, Nelson, 1970, Zeithaml, 1988). 
In this paper only price, advertising and warranties have been chosen for analysis because they were thought to be the primary marketing variables that might be related to TQM and because they have received the majority of attention in the literature. Although there are some studies relating perceived quality with retailer reputation (e.g., Wheatley and Chiu, 1977, Dodds et al., 1991 and Rao and Monroe, 1989), it has not received as much attention as price, warranties and advertising. Furthermore, although sales force, publicity, and distribution are important marketing variables, they are not employed by all companies and it was the purpose of this preliminary cross-sectional study to be as general as possible.

The way in which price, advertising and warranties impinge on the perceived quality for a particular company will depend on how they are used and deployed by competing companies. These variables are also employed by the consumer to make comparisons between different brands.

Table 3 summarizes the theoretical and empirical studies that have examined the relationship between perceived quality and the external attributes considered in this paper (i.e. advertising, price and warranties) using a three part categorisation - "in favour of the existence of", "in favour only in certain cases", or "against such an impact”. Many authors consider that consumers use price as a quality indicator, at least in certain cases, however, Caves and Green (1996), Curry (1985), Curry and Riesz (1988), Dardis and Gieser (1980), Geistfeld (1982), Gerstner (1985), Hjorth-Andersen (1991), Sproles (1977) and Tellis and Wernerfelt (1987) have found that price is not a good indicator of intrinsic quality. A higher price may indicate better quality (e.g. designer fashion label) and may motivate purchasers but it may also discourage them. Some companies appear to use high prices to indicate high quality although their product quality may be no better than that of their competitors and consumers may also use advertising and warranties to infer quality. 


\section{A proposed framework linking TQM, extrinsic attributes and company results}

Figure 1 illustrates a proposed framework to represent the possible relationships between TQM, price, advertising and warranties and their effects on unit cost of production, growth in market share and operational profits. Growth in market share and unit cost of production were chosen as measures of performance because the use of specific quality management measures such as 'rate of defects', omits relevant details (e.g. investment in TQM) and financial measures, such as share prices, are affected by other factors (e.g. interest rates), which are not related to TQM policy.

\section{$<$ Take in Fig 1 here $>$}

The hypotheses underpinning this framework model are presented and discussed below.

H1. Marketing mix variables are mutually interrelated.

The existence of a relationship between price, advertising and warranties would indicate that companies use them jointly; that is to say, when a company establishes a high price it spends more on advertising and/or on warranties and vice versa. The reason for this could be that when consumers use the extrinsic attributes of a product to infer and judge its quality, companies act accordingly and use these extrinsic attributes to present the image that their products are superior. Farris and Reibstein (1979) demonstrated that companies with consistent pricing and advertising strategies produced higher returns on investment than companies with inconsistent strategies.

H2. No clear relationship between TQM dimensions and marketing variables. 
A positive relationship between TQM and price, advertising and warranties could indicate that those companies which make considerable efforts in improving quality communicate this to consumers by means of extrinsic attributes and, at the same time, aim to obtain increased prices for their products. However, better quality products may need less extrinsic attributes in order to sell, therefore, companies who produce better quality products may use extrinsic attributes to a lesser degree, and, in this case, the relationship between TQM and extrinsic attributes would be negative. Moreover, it is not unusual to find a lack of co-ordination between marketing and production departments with the marketing strategy being decided by the marketing department and the TQM policy being the responsibility of production departments.

H3. Marketing variables are related to market share growth:

1. Advertising is positively related to market share growth through a positive relationship with perceived quality.

2. Warranties are positively related to market share growth through a positive relationship with perceived quality

3. Price does not have a relationship with market share growth.

As perceived quality not only depends on physical attributes but also on marketing strategy then price, advertising and warranties should have a positive relationship with perceived quality. Price also have a positive relationship with consumer expenditure. Neither perceived quality nor consumer expenditure have been assessed in the analysis and are therefore latent variables in the framework. If perceived quality has a positive relationship with market share growth, then advertising and warranties should have a positive relationship with market share growth. Thus the expected effect of price (in the normal range of prices) on market share growth is null, since the negative effect of perceived expenditure counteracts the positive effect of perceived quality on market 
share growth. This lack of relationship would not be expected to exist for any price because extremely high prices imply reductions in market share.

H4. TQM is positively related to market share growth through a positive relationship with intrinsic quality attributes.

Adam (1994), Adam et al. (1997) and Flynn et al. (1995) have shown that TQM helps to improve intrinsic quality through reduced defect rates and better design. Also intrinsic quality (another latent variable in the model) has a positive effect on consumer perceptions of quality (Flynn et al., 1995), and that perceived quality has a positive effect on growth in market share (Jacobson and Aaker, 1987, Phillips et al., 1983).

H5. TQM is negatively related to unit production cost.

TQM is claimed to contribute to reduced costs (e.g., Adam, 1994, Adam et al., 1997, Crosby, 1987 and Dale and Plunkett, 1995).

H6. Higher production costs are not positively related to market share growth.

Better design characteristics (intrinsic attributes) may require increasing the cost of the product. They also imply improved perceived quality and consequently may imply an improvement in market share growth. However, differences in costs are not only due to differences in attributes but also to differences in efficiency. Moreover, when higher quality is achieved with more intrinsic attributes, and, therefore, an increase in costs, a higher market share need not follow because the increase in price needed to maintain the benefit counteracts the effect of higher quality. All these elements imply a null (neither negative nor positive) effect of production cost on market share.

H7. Market share growth and unit production costs are related to operational profits: 
1. Market share growth is positively related to operational profits

2. Unit production costs are negatively related to operational profits.

The operational profits of companies are clearly dependent upon sales and costs. Therefore, companies with larger market share growth (Buzzell et al., 1975) and with smaller unit costs (Phillips et al., 1983) will obtain better operational profits. 


\section{Research methodology}

The population comprised industrial companies with factories located in Spain. Industrial companies were chosen because the problems faced in the management of quality by service companies are different (Dale et al., 1997, Benson et al., 1991). A list of the 3000 largest Spanish companies by annual sales turnover is published by the organization "Fomento de la Producción" of which 1105 were surveyed. The target respondents of the questionnaire were general managers because they should be the TQM leaders in their respective companies. When the name of the general manager unknown, the questionnaire was addressed to "responsable de calidad" (quality leader) and the first question asked for the position of the respondent in the company.

The questionnaire response rate was 20.2\% (223 companies), and this is comparable to those of recent operations management studies by Mehra and Inman (1992), Small and Yasin (1997) and Vickery et al. (1997). The majority of the questionnaires were answered by quality managers (63.1\%); other major respondents were general managers (26\%), quality department representatives (6.6\%) and staff members (5.1\%). Variance analysis indicates that the position of the respondents did not affect the responses. Correlation between the number of companies in each sector of the population and the number of companies in each industry of the sample were positive and significant $(\mathrm{r}=0.7023, \mathrm{p}=$ 0.000), indicating that the sample represented the sectors analyzed. Some $45 \%$ of the companies in the sample are made up of foreign companies, mainly of European, United States and Japanese origin as shown in Table 4.

A postal questionnaire method, in which anonymity was assured, was used. The questionnaire (see Appendix) was based on a previous survey and research study (Gallego 
and Martinez, 1994) and was subjected to a formal pre-test involving three quality managers and one quality consultant of a local chamber of commerce in Spain and then critically reviewed by six professors of management at the University of Murcia, who were outside the research team. All questions were answered in relation to the main product of the company with subjective opinions requested. Dess and Robinson (1984) and Pearce et al. (1987) demonstrated a high correlation between subjective opinions and precise data and it was recognized that precise data could not be obtained due to the different definitions of financial criteria employed by companies and industrial sectors. Therefore, respondents were asked to indicate their opinions about how their respective organizations compared to the competition in relation to:

a) unit cost of manufacturing during the past 5 years

b) earnings before interest and tax over sales (EBIT/S) during the past 5 years

c) advertising expenditure

d) price of the product

e) the warranties offered

Respondents were also asked to indicate their opinions on the variation of the market share of their company during the past 5 years.

The design of a construct using a similar methodology to that of Ahire et al. (1996), Flynn et al. (1994) and Saraph et al. (1989) was chosen to assess the development of TQM employing the seven TQM dimensions described in Table 2.

Employee Relations (ER), Organisation (O), Product Design Process (PDP), Quality Information (QI) and Supplier relationships (SR) were measured on a five-point scale from 1 (Strongly disagree) to 5 (Strongly agree) whilst Process Instruments (PI) and Design Instruments (DI) were measured on a 0 to 5 scale, with 0 (do not use the instrument), 1 
(use the instrument at a low level) and 5 (use the instrument at a high level). The average of the points obtained in each question for each dimension were computed. Reliability of each TQM dimension was measured using the internal consistency method, as described by Bohrnstedt (1970). Items that reduce the total Cronbach's alpha were eliminated in order to maximize reliability. Typically, reliability coefficients of 0.7 or more are considered adequate, however, coefficients of 0.6 can be accepted for new scales (Nunnally, 1978). Thus a decision was taken to accept (with some reservations) those dimensions with Cronbach’s alpha from 0.6 to 0.7 .

\section{<Take in Table 5 here $>$}

Except for Supplier Relationship (SR), with Cronbach’s alpha of 0.57, all other dimensions were found to have an alpha between 0.88 and 0.67 and therefore the Supplier Relationship (SR) dimension was omitted from the analysis. The low alpha for the Supplier Relationship (SR) dimension could be due to small companies having difficulties in encouraging suppliers, who are often large organizations for whom the supplier business represents only a small proportion of their sales, to apply a specific tool, technique and/or system. It is also equally problematic for a small company to involve large organization suppliers in the NPDD process (Spring et al., 1998). Therefore, small companies committed to TQM can only apply elements of this dimension that do not depend on the decisions of their suppliers.

Two criteria, content validity and construct validity, were employed as proposed by Bohrnstedt (1970), Campbell and Fiske (1959) and Magnusson (1976). Content validity tests if the scale used is based on related theory. The scale used encompassed the dimensions that constitute TQM and selection of the measurement items was based on an 
exhaustive review of the literature (Martinez, 1997). Construct validity indicates the degree to which all the questions in a scale measure the same construct and several procedures can be applied (Bagozzi et al., 1991). Factor analysis was employed to determine if more than one explanatory factor existed for each dimension and confirmed that the items of each dimension were loaded on a single factor (with eigenvalue $>1$ ) indicating that each dimension measured only one facet of TQM. Finally, an element of construct validity, convergent validity, was also considered. This measures the degree to which the different dimensions, into which the construct is divided, are positively correlated amongst themselves (i.e. dimensions that belong to the same construct are expected to be highly correlated). The correlations obtained were all positive and significant at $\mathrm{p}<0.05$.

After confirming reliability and validity and suppressing the Supplier Relationship dimension the levels of each TQM dimension for each company were calculated. The means and standard deviations of the obtained values are given in Table 6 and summary statistics for the measures of performance and marketing mix variables are in Table 7.

\section{<Take in Table 6 here $>$}

\section{<Take in Table 7 here $>$}

In order to contrast the existence of each proposed relationship, Kendall's tau-c was employed (Kendall and Gibbons, 1990) due to the existence or ranked variables (marketing and performance variables). A transformation of the TQM dimensions using a 1 to 5 point scale (each point being 1/5th of the range of each dimension) was performed in order to transform these variables in ranked variables. 


\section{Results and discussion}

Each of the relationships presented in Figure 1 are examined in detail in the light of the survey results under four main headings.

\section{Marketing mix variables and TQM dimensions}

Table 8 shows the Kendall's tau-c values for the relationships between price, advertising, warranties and the TQM dimensions. A positive relationship exists between the three extrinsic marketing mix variables suggesting that companies use them all to a similar degree. This appears to support hypothesis $H 1$ that companies maintain a consistent marketing strategy in relation to price, advertising and warranties. The relationship of price with advertising and warranties could also be due to the fact that expenditures in the latter are translated to the price of the product. This result was expected, as marketing departments do not make decisions on the marketing mix variables in isolation and further confirms the validity of the survey responses.

\section{<Take in Table 8 here $>$}

However there is a lack of a general relationship between the three extrinsic variables and the TQM dimensions, as predicted in hypothesis H2. No relationship was found with advertising and any of the TQM dimensions; the only significant relationships were between PDP and warranties and between $\mathrm{O}$ and price. The former could mean that companies who have an effective design process are more confident in the reliability of their products and, consequently, can offer more extended warranties. The latter suggests that companies might believe that investments in the $\mathrm{O}$ dimension (e.g. the application of a quality management system standard) can be recovered with a higher price due to the improved quality. However, applying the same logic, more 
positive relationships would have been expected. For example, because PDP has a relationship with warranties then so should DI, since the use of these tools and techniques can improve reliability. Thus, whilst the marketing mix strategy of the responding companies reveals a general concordance of the three variables of price, advertising and warranties, this strategy is not generally related to the factors which constitute the TQM dimensions. There could be two main reasons for this finding:

(a) Although TQM should be applied company wide, frequently it is restricted to production departments and a lack of communication and co-ordination between production and marketing departments would explain the lack of linkage between TQM and marketing strategies.

(b) It is possible that some companies try to reinforce their TQM efforts with a marketing policy that communicates to consumers the improvements, which have been made and then they increase prices, increase expenditure on advertising and extend warranties. On the other hand, it is also possible that companies may make the most of the improved quality achieved and consequently reduce expenditures on advertising and warranties as this is no longer necessary to convince consumers of superior quality. Moreover, they may also make the most of reduced cost achieved with such a policy and reduce prices accordingly. The combined effects of these different company policies could have resulted in the lack of relationship between TQM and extrinsic attributes. 


\section{Marketing variables, unit costs and market share growth}

Table 9 shows the relationship of the marketing variables and unit cost with market share growth. The results indicate that advertising affects market share growth but that price, warranties and unit costs do not. Therefore, hypothesis H3.1 was confirmed and again supports evidence elsewhere in the literature. This does not mean that companies should invest unreservedly in advertising, since advertising also has a cost.

\section{<Take in Table 9 here >}

The lack of a relationship between price and market share growth supports hypothesis H3.3: the negative effect of price on the purchase decision may be counteracted by the positive effect on product quality image. As stated in the explanation of hypothesis H3.3, this is limited to normal prices and prices are generally normal due to the fact that companies set prices in relation to competitors. It is only when price moves outside the normal range that it has value as a marketing tool.

The fact that warranties did not appear to have relevance refutes hypothesis H3.2. This finding appears to concord with that of Boulding and Kirmani (1993), who found that high warranty is beneficial only to the high-credibility firm and not to the lowcredibility firm. Other researchers, for example, Cooper and Ross (1985), Gal-Or (1989), Lutz (1989) and Spence (1977) claim that warranties are not a rational indicator of product quality. Therefore, if low credibility firms offer high warranties, they will not obtain higher market share. 


\section{TQM dimensions, unit costs and market share growth}

Table 10 shows the Kendall's tau-c for the relationships between the TQM dimensions and market share growth and unit costs. Only ER and DI have a significant relationship with market share growth and only ER showed a significant relationship with unit costs. Therefore, hypotheses $H 4$ and $H 5$ have been only partially confirmed. Although this finding is not in accordance with TQM theory, it has similarities with previous research findings. Adam (1994), Anderson et al. (1995) and Powell (1995) did not find any relationship between most of their TQM dimensions and measures of company performance, except for those related to workforce management. Adam et al. (1997), found that the factors positively related to financial performance were 'senior management involvement' and 'employee compensation and recognition', both of which are included in the ER dimension. Flynn et al. (1995) reported that TQM dimensions related to the PDP were regarded as most important to achieve high perceived quality.

\section{$<$ Take in Table 10 here $>$}

The lack of a relationship between O, QI, PI and DI and performance is counterintuitive and cannot be explained by the literature and might be explained by incorrect application of TQM tools and practices. Dale and Lightburn (1992) and Wheeler (1994) have reported several examples of misunderstandings about the application of SPC (Statistical Process Control). 


\section{Market share growth and unit costs related to Operational Profits}

No significant relationship was found between unit production costs and market share growth, confirming hypothesis H6 (Table 9). Since a positive and significant relationship (tau-c $=0.20, \mathrm{p}=0.00$ ) between price and unit cost was found then higher cost and higher prices are related.

Growth in market share is positively related to EBIT/S (tau-c $=0.176, \mathrm{p}=0.001$ ) whilst unit costs have a negative relationship (tau-c $=-0.157, \mathrm{p}=0.007$ ) thus confirming hypotheses H7.1 and H7.2.

\section{$\underline{\text { A revised framework }}$}

A revised model, with all significant Kendall's tau-c coefficients (at $\mathrm{p}<0.05$ ), is presented below in Figure 2.

$<$ Take in Figure 2 here $>$ 


\section{Conclusions}

This paper has explored three phenomena - TQM, marketing mix and measures of business performance based on empirical research in Spanish manufacturing companies. The concept of perceived quality (before and after purchase) was examined by reference to the diverse marketing and quality management literature and relates not only to intrinsic product characteristics but also includes external attributes. A framework model was developed and tested to examine relationships amongst and between six TQM dimensions (Employee Relationships, Organisation, Product Design Process, Quality Information, Supplier Relationships, Process Instruments and Design Instruments), three marketing mix variables (price, advertising and warranties) and three measures of company performance (market share growth and production costs per unit and operational profits (EBIT/S)). The relationships were examined using nonparametric correlation analysis to offer a first attempt at cross-functional fertilization between TQM, marketing mix variables and measures of business performance.

This paper examines the relationships between TQM dimensions and measures of company performance and also tries to offer a first attempt by analyzing the relationships between some marketing mix variables and those TQM dimensions that affect perceived quality. This is an important issue because the results of TQM should be analyzed in a wider context (i.e. in relation to overall company strategy).

With respect to price, advertising and warranties, the results confirm what would be expected, that companies use them jointly as part of a marketing strategy. The analysis of the relationship of these marketing mix variables with market share growth showed that only advertising had a positive effect. On the other hand, price was found to have no relationship with market share growth, indicating that its effect as a quality indicator 
counterbalances its effect as a disincentive to sales. Warranties appear to be an unimportant variable with respect to growth in market share.

No relationship between external attributes and TQM dimensions were found. This supports anecdotal evidence of a lack of functional integration between operations and marketing departments and may also result from companies defining their strategy in relation to external and internal attributes according to the characteristics of the different markets, as suggested by Hill (1985). Further research to analyze the company behaviour in different markets and circumstances could clarify this.

The only TQM dimensions that showed a positive and significant relationship with market share growth were Employee Relations and Design Instruments. Only Employee Relations had a negative and significant relationship with unit cost in relation to competitors. This finding, supported by previous research (e.g., Adam, 1994, Adam et al., 1997, Anderson et al., 1995, Flynn et al., 1995 and Powell, 1995), appears to indicate that the key elements of a TQM policy are workforce management and the use of the quality management-related design tools.

The implications for management are clear. First, management should examine the relationships between their marketing and operations departments and analyze whether their company marketing mix strategy fits with their TQM policy and how this relates to the overall company strategy. Second, they should recognize that workforce management is the primary driver of TQM and also examine whether the TQM tools and practices are being correctly implemented. A corollary is that there may also be some merit in examining the relationships between the system of human resources management and operations departments to ensure that workforce management 
practices are supporting TQM policies and that employees have appropriate skills to implement these policies, practices and tools.

The study is not without its limitations. The data obtained are perceptual data, with all the associated problems. Future studies including objective data would be interesting and further work should be undertaken to include additional data. In particular, additional elements of marketing (e.g. market position, sales promotions, publicity and distribution) should be considered and the measurement of quality in the eyes of the consumers would be of value. It would also be useful to analyze the differences between industries, since the use and effect of marketing variables might exhibit different effects. Longitudinal research to consider the time lags of the effect of TQM on performance would also be of value (Reed et al., 1996). Finally, Kendall's tau-c only measures association and does not indicate causality or the strength of relationships, which could be investigated by further research. 


\section{REFERENCES}

Aaker, D. and Jacobson, R., (1994), "The financial information content of perceived quality", Journal of Marketing Research, Vol. 31, No. 2, pp. 191-201.

Adam, E. E. Jr., (1994).“Alternative quality improvement practices and organization performance”, Journal of Operations Management, Vol. 12, No. 1, pp. 27-44.

Adam, E. E. Jr., Corbett, L. M., Flores, B. E., Harrison, N. J., Lee, T. S., Rho, B., Ribera, J., Samson, D. and Westbrook, R., (1997). "An international study of quality improvement approach and firm performance”, International Journal of Operations and Production Management, Vol. 17, No. 9, pp. 842-873.

Ahire, S. L., Golhar, D. Y. and Waller, M. A.,(1996). "Development and validation of TQM implementation constructs”, Decision Sciences, Vol. 27, No. 1, pp. 23-56.

Allen, F., 1984. "Reputation and product quality”, Rand Journal of Economics, Vol. 15, No. 3, pp. 311-327.

American Quality Foundation and Ernst \& Young, (1991). International Quality Study: the Definitive Study of the Best International Quality Management Practices, Ernst \& Young, Cleveland, OHIO.

Anderson, E. W., Fornell, C. and Lehmann, D. R., (1994). "Customer satisfaction, market share, and profitability: findings from Sweden”, Journal of Marketing, Vol. 58, No. 3, pp. 53-66.

Anderson, J. C., Rungtusanatham, M., Schroeder, R. G. and Devaraj, S., (1995). "A path analytic model of a theory of quality management underlying the Deming management method: preliminary empirical findings”, Decision Sciences, Vol. 26, No. 5, pp. 637-658.

Bagozzi, R. P. and Yi, Y. and Phillips, L. W., (1991). "Assessing construct validity in organizational research”, Administrative Science Quarterly, Vol.36, No.3, pp. 421-458.

Balachander, S. and Srinivasan, K., 1994. "Selection of product line qualities and prices to signal competitive advantage”, Management Science, Vol. 40, No. 7, pp. 824-841.

Benson, P. G., Saraph, J.V. and Schroeder,R. G.(1991). "The effects of organizational context on quality management: an empirical investigation", Management Science, Vol.37, No.9, pp.11071124.

Bohrnstedt, G. W., (1970). "Reliability and validity assessment in attitude measurement”, in: G. F. Summers (Ed), Attitude Measurement, Rand McNally \& Co., Chicago, pp. 80-99.

Boulding, W. and Kirmani, A.,(1993). "A consumer side experimental examination of signaling theory: do consumers perceive warranties as signals of quality?”, Journal of Consumer Research, Vol. 20, No. 1, pp. 111-123.

Buzzell, R. D., Gale, B. T. and Sultan, R. G. M., (1975). "Market share- a key to profitability", Harvard Business Review, Vol. 53, No. 1, pp. 97-106.

Campbell, D. T. and Fiske, D. W., (1959). "Convergent and discriminant validation by the multitrait-multimethod matrix”, Psychological Bulletin, Vol. 56, No. 1, pp. 81-105.

Capon, N., Farley, J. U. and Hoenig, S., (1990). "Determinants of financial performance: a metaanalysis”, Management Science, Vol. 36, No. 10, pp. 1143-1159. 
Caves, R. E. and Greene, D. P.,(1996). "Brands' quality levels, prices, and advertising outlays: empirical evidence on signals and information costs". International Journal of Industrial Organization, Vol. 14, No. 1, pp. 29-52.

Cooper, R. and Ross, T. W., (1984). "Prices, product qualities and asymmetric information, the competitive case”, Review of Economic Studies, Vol. 51, pp. 197-207.

Cooper, R. and Ross, T. W., (1985). "Product warranties and double moral hazard”, Rand Journal of Economics, Vol. 16, No. 1, pp. 103-113.

Craig, C. S. and Douglas, S. P., (1982). "Strategic factors associated with market and financial performance”,Quarterly Review of Economics and Business,Vol.22, No.2, pp.101-112

Crosby, P. B., (1987). Quality Is Free. The Art of Making Quality Certain, McGraw-Hill, N.Y.

Curry, D. J., (1985). "Measuring price and quality competition", Journal of Marketing, Vol. 49, No. 2, pp. 106-117.

Curry, D. J. and Riesz, P. C.,(1988). "Prices and price/quality relationships: a longitudinal analysis”, Journal of Marketing, Vol. 52, No. 1, pp. 36-51.

Dale, B. G. and Lightburn, K.,(1992). "Continuous quality improvement: why some organizations lack commitment", International Journal of Production Economics, Vol. 27, No. 1, pp. 57-67.

Dale, B. G. and Plunkett, J. J., (1995). Quality Costing , Chapman \& Hall, London.

Dale, B. G., Williams, A. R. T., Barber, K. D. and van der Wide, T., (1997). "Managing quality in manufacturing versus services: a comparative analysis”, Managing Service Quality, Vol. 7, No. 5, pp. 242-247.

Darby, M. R. and Karni, E., (1973). "Free competition and the optimal amount of fraud”, Journal of Law and Economics, Vol. 16, pp. 67-86.

Dardis, R. and Gieser, N., 1980. "Price and quality of durable goods: are they more closely related in the seventies than in the sixties?", Journal of Consumer Policy, Vol. 4, No. 3, pp. 238-247.

Dess, G. and Robinson, R. B. Jr., (1984). "Measuring organizational performance in the absence of objective measures: the case of the privately held firm and conglomerate business unit”, Strategic Management Journal, Vol. 5, pp. 265-273.

Dodds, W. B., Monroe, K. B. and Grewal, D., (1991). "Effects of price, brand, and store information on buyers' product evaluations", Journal of Marketing Research, Vol. 28, No. 3, pp. 307-319.

Farris, P. W. and Reibstein, D. J., (1979). "How prices, ad expenditures, and profits are linked”, Harvard Business Review, Vol. 57, No. 6, pp. 173-184.

Feigenbaum, A. V., (1983). Total Quality Control. Engineering and Management (3rd ed.), McGraw-Hill, New York.

Fisher, T. J., (1992). “The impact of quality management on productivity”, International Journal of Quality and Reliability Management, Vol. 9, No. 3, pp. 44-52.

Flynn, B. B., Schroeder, R. G. and Sakakibara, S., (1994). "A framework for quality management research and an associated measurement instrument", Journal of Operations Management, Vol. 11, No. 4, pp. 339-366. 
Flynn, B. F., Schroeder, R. G. and Sakakibara, S., (1995). "The impact of quality management practices on performance and competitive advantage”, Decision Sciences, Vol. 26, No. 5, pp. 659691.

Forker, L. B., (1997). "Factors affecting supplier quality performance”, Journal of Operations Management, Vol. 15, No. 4, pp. 243-269.

Fuchsberg, G., (1993a). "Baldrige award may be losing some luster”, Wall Street Journal, April,

Fuchsberg, G., (1993b). “Small firms struggle with latest management trends”, Wall Street Journal, August,

Gabor, A. and Granger, C. W. J., (1966). "Price as an indicator of quality: report on an inquiry", Economica, Vol. 33, No. 129, pp. 43-70.

Gale, B. T. and Buzzell, R. D.,(1989). "Market perceived quality: key strategic concept”, Planning Review, Vol. 17, No. 2, pp. 6-15, 48.

Gallego Rodriguez, A., Martinez Lorente, A. R., (1994). “Análisis de la aplicación de la gestión de la calidad en las empresas de transformación metálica de la Comunidad AutóNoma de la Región de Murcia”, CuaderNos de EcoNomía Murciana, No. 10, pp. 14-37.

Gal-Or, E., (1989). “Warranties as signal of quality”, Canadian Journal of Economics, Vol. 22, No.1, pp. 50-61.

Gardner, D. M., (1971). “Is there a generalized price-quality relationship?” Journal of Marketing Research, Vol. 8, No. 2, pp. 241-243.

Garvin, D. A. (1988). Managing quality, The Free Press, New York.

Geistfeld, L. V., (1982). "The price-quality relationship revisited", The Journal of Consumer Affairs, Vol. 16, No. 2, pp. 334-346.

Gerstner, E., (1985). "Do higher prices signal higher quality?”, Journal of Marketing Research, Vol. 22, No. 2, pp. 209-215.

Gotlieb, J. B. and Sarel, D.,(1992). "The influence of type of advertisement, price, and source credibility on perceived quality”, Journal of the Academy of Marketing Science, Vol. 20, No. 3, pp. 253-260.

Hendricks, K. B. and Singhal, V. R.,(1996). "Quality awards and the market value of the firm: an empirical investigation”, Management Science, Vol.42, No.3, pp.415-436.

Hendricks, K. B. and Singhal, V. R., (1997). "Does implementing an effective TQM program actually improve operating performance? Empirical evidence from firms that have won quality awards”, Management Science, Vol.43, No.9, pp.1258-1274.

Hertzendorf, M. N., (1993). “I'm Not a high quality firm, but I play one on TV”, Rand Journal of Economics, Vol. 24, No. 2, pp. 236-247.

Hill, T., (1985). Manufacturing Strategy. Irwin.

Hjorth-Andersen, C.,(1991). "Quality indicators in theory and in fact", European Economic Review, Vol. 35, No. 8, pp. 1491-1505. 
Ishikawa, K., (1985). What is total quality control. The Japanese way, Prentice-Hall, N.Y.

Ittner, C. D. and Larcker, D., (1997). "The performance effects of process management techniques”, Management Science, Vol. 43, No. 4, pp. 522-534.

Jacobson, R. and Aaker, D. A., 1987. "The strategic role of product quality”, Journal of Marketing, Vol. 51, No. 4, pp. 31-44.

Kano, N, Tanaka, H. and Yamaga, Y., (1983). The TQC Activity of Deming Prize Recipients and its Economic Impact, Union of Japanese Scientists and Engineers, Tokyo.

Kendall, M. and Gibbons, J. D., (1990). Rank Correlation Methods, (5th ed.), Oxford University Press, New York.

Kihlstrom, R. E. and Riordan, M. H., (1984). “Advertising as a signal”, Journal of Political EcoNomy, Vol. 92, No. 3, pp. 427-451.

Kirmani, A. and Wright, P.,(1989). "Money talks: perceived advertising expense and expected product quality”, Journal of Consumer Research, Vol. 16, No. 3, pp. 344-353.

Kotler, P.,(1980). Marketing management. Analysis, planning, and control, Prentice/Hall International, London.

Kuehn, A. A. and Day, R. L.,(1962). "Strategy of product quality”, Harvard Business Review, Vol. 40, No. 6, pp. 100-110.

Larry, L.,(1993).“Betting to win on the Baldrige winners”, Business Week,18th Oct. pp.16-17.

Lambert, D. R., (1980). "Price as a quality signal: the tip of the iceberg”, Economic Inquiry, Vol. 18, pp. 144-150.

Lichtenstein, D. R. and Burton, S., (1989). "The relationship between perceived and objective price-quality”, Journal of Marketing Research, Vol. 26, No. 4, pp. 429-443.

Lutz, N. A., (1989). "Warranties as signals under consumer moral hazards", RAND Journal of Economics, Vol. 20, No. 2, pp. 239-255.

Magnusson, D., (1976). Teoría de los tests (1st. Spanish ed., 1966), Trillas, México.

Martinez Lorente, A. R., (1997). Gestión de la calidad en la producción. Revisión teórica y análisis de su implantación y resultados en España, Doctoral Thesis, University of Murcia, Spain.

Martinez-Lorente, A. R., Gallego-Rodríguez, A. and Dale, B. G. (1998a), Total quality management and company characteristics:an examination. Quality Management Journal, Vol. 5, No. 4, pp59-71.

Martinez-Lorente, A.R., Dewhurst F.W. \& Dale, B.G,(1998b),“Total Quality Management: Origins and Evolution of the Term”, The TQM Magazine, Vol 10, No.5, pp378-386

Mathews, J., (1992). "The cost of quality", Newsweek, September, pp. 48-49.

Mehra, S. and Inman, R. A., (1992). "Determining the critical elements of just-in-time implementation”, Decision Sciences, Vol. 23, No. 1, pp. 160-174. 
McConnell, J. D., (1968). “The price-quality relationship in an experimental setting”, Journal of Marketing Research, Vol. 5, No. 3, pp. 300-303.

McGuire, J. B., Schneeweis, T. and Branch, B., (1990). "Perceptions of firm quality: a cause or result of firm performance”, Journal of Management, Vol. 16, No. 1, pp. 167-180.

Milgrom, P. and Roberts, J., (1986). "Price and advertising signals of product quality”, Journal of Political Economy, Vol. 94, No. 4, pp. 796-821.

Mizuno, M. and Odagiri, H., 1990. "Does advertising mislead consumers to buy low quality products?” International Journal of Industrial Organization, Vol. , No. 4, pp. 545-558.

Naj, A., (1993). "Some manufacturers drop efforts to adopt Japanese manufacturing techniques", Wall Street Journal, April.

National Institute of Standards and Technology, (1998). "Baldrige Index out-performs S\$P 500 for fourth year”, National Institute of Standards and Technology, February.

Nelson, P., (1970). "Information and consumer behavior”, Journal of Political Economy, Vol. 78, No. 2, pp. 311-329.

Nelson, P., 1974. “Advertising as information”, Journal of Political Economy, Vol. 81, No. 4, pp. 729-754.

Nunnally, J. C., (1978). Psychometric theory, McGraw-Hill, New York.

Pearce, J., Robbins, K., Robinson, R. Jr., (1987). “The impact of grand strategy and planning formality on financial performance”, Strategic Management Journal, Vol. 8, No. 2, pp. 125-134.

Pechmann, C. and Ratneshwar, S., 1992. "Consumer covariation judgments: theory or data driven?” Journal of Consumer Research, Vol. 19, No. 3, pp. 373-386.

Phillips, L. W., Chang, D. R. and Buzzell, R. D., (1983). "Product quality, cost position and business performance: a test of some key hypotheses", Journal of Marketing, Vol. 47, No. 2, pp. 26-43.

Powell, T. C., (1995). “Total quality management as competitive advantage: a review and empirical study”, Strategic Management Journal, Vol. 16, No. 1, pp. 15-37.

Rao, A. R. and Monroe, K. B., (1989). "The effect of price, brand name, and store name on buyers' perceptions of product quality: an integrative review”, Journal of Marketing Research, Vol. 26, No. 3, pp. 351-357.

Reed, R., Lemak, D. J. and Montgomery, J. C., (1996). "Beyond process: TQM content and firm performance”, Academy of Management Review, Vol. 21, No. 1, pp. 173-202.

Saraph, J. V., Benson, P. G. and Schroeder, R. G., (1989). “An instrument for measuring the critical factors of quality management”, Decision Sciences, Vol.20, No.4, pp. 810-829.

Schmalensee, R., (1978). "A model of advertising and product quality”, Journal of Political Economy, Vol. 86, No. 3, pp. 485-503.

Sjolander, R., (1992). “Cross cultural effects of price on perceived product quality”, European Journal of Marketing, Vol. 26, No. 7, pp. 34-44. 
Small, M. H. and Yasin, M. M.,(1997). "Advanced manufacturing technology: implementation policy and performance”, Journal of Operations Management, Vol.15, No.4,pp.349-370

Spence, M.,(1977). “Consumer misperceptions, product failure and producer liability”, Review of Economic Studies, Vol. 44, No. 3, pp. 561-572.

Spring, M., McQuater, R. E., Swift, K., and Dale, B. G., 1998. "The use of quality tools and techniques in product innovation. An assessment methodology”, The TQM Magazine, 10, 1,

Sproles, G. B.,(1977). "New evidence on price and product quality", The Journal of Consumer Affairs, Vol. 11, No. 1, pp. 63-77.

Stafford, J. E. and Enis, B. M., (1969). “The price-quality relationship: an extension”, Journal of Marketing Research, Vol. 6, No. 4, pp. 456-458.

Tellis, G. J. and Fornell, C., (1988). "The relationship between advertising and product quality over the product life cycle: a contingency theory”, Journal of Marketing Research, Vol. 25, No. 1, pp. 64-71.

Tellis, G. J. and Wernerfelt, B. (1987). "Competitive price and quality under asymmetric information", Marketing Science, Vol. 6, No. 3, pp. 240-253.

U.S. General Accounting Office, (1991). "Management practices: U.S. companies improve performance through quality efforts”, U.S. General Accounting Office, Gaithersburg,

Vickery, S. K., Dröge, C. and Markland, R. E.,(1997). "Dimensions of manufacturing strength in the furniture industry”, Journal of Operations Management,Vol.15, No.4,pp.317-330

Wheatley, J. J. and Chiu, J. S., (1977). "The effects of price, store image, and product and respondent characteristics on perceptions of quality”, Journal of Marketing Research, Vol. 14, No. 2, pp. 181-186.

Wheeler, D. J., (1994). "Charts done right”, Quality Progress, Vol. 27, No. 5, pp. 65-68.

White, P. D. and Cundiff, E. W., (1978). “Assessing the quality of industrial products”, Journal of Marketing, Vol. 42, No. 1, pp. 80-86.

Wisner, J. D. and Eakins, S. G., (1994). “Competitive Assessment of the Baldrige Winners”, International Journal of Quality and Reliability Management, Vol. 11, No. 2, pp. 8-25.

Wolinsky, A., (1983). "Prices as signals of product quality”, Review of Economic Studies, Vol. 50, pp. 647-658.

Zeithaml, V. A., (1988). "Consumer perceptions of price, quality, and value: a means-end model and synthesis of evidence”, Journal of Marketing, Vol. 52, No. 3, pp. 2-22. 


\begin{tabular}{|c|c|c|c|c|}
\hline & \multicolumn{2}{|c|}{$\begin{array}{c}\text { Supporting TQM theory } \\
\text { (positive relationships) }\end{array}$} & \multicolumn{2}{|c|}{$\begin{array}{c}\text { Not supporting TQM theory } \\
\text { (negative or null relationships) }\end{array}$} \\
\hline & $\begin{array}{l}\text { TQM } \\
\text { dimension }\end{array}$ & $\begin{array}{l}\text { Measure of } \\
\text { performance }\end{array}$ & $\begin{array}{l}\text { TQM } \\
\text { dimension }\end{array}$ & $\begin{array}{l}\text { Measure of } \\
\text { performance }\end{array}$ \\
\hline $\begin{array}{l}\text { Adam } \\
(1994)\end{array}$ & $\begin{array}{l}\text { Workforce and } \\
\text { top management } \\
\text { commitment } \\
\end{array}$ & Return on investment & $\begin{array}{l}\text { All the TQM } \\
\text { factors identified in } \\
\text { his research }\end{array}$ & $\begin{array}{l}\text { Sales growth and net } \\
\text { income }\end{array}$ \\
\hline $\begin{array}{l}\text { Adam et al } \\
\text { (1997) }\end{array}$ & $\begin{array}{l}\text { Senior } \\
\text { management } \\
\text { involvement and } \\
\text { employee } \\
\text { compensation and } \\
\text { recognition }\end{array}$ & Financial performance & $\begin{array}{l}\text { Knowledge of } \\
\text { quality }\end{array}$ & Financial performance \\
\hline $\begin{array}{l}\text { Anderson } \\
\text { et al } \\
(1995) \\
\end{array}$ & $\begin{array}{l}\text { Employee } \\
\text { fulfillment }\end{array}$ & Customer fulfillment & $\begin{array}{l}\text { Continuous } \\
\text { improvement }\end{array}$ & Customer fulfillment \\
\hline $\begin{array}{l}\text { Flynn et al } \\
\text { (1995) }\end{array}$ & $\begin{array}{l}\text { Product design } \\
\text { Process flow } \\
\text { management } \\
\end{array}$ & $\begin{array}{l}\text { Quality perceived in } \\
\text { the market. Rate of } \\
\text { defectives }\end{array}$ & $\begin{array}{l}\text { Process flow } \\
\text { management }\end{array}$ & $\begin{array}{l}\text { Quality perceived in the } \\
\text { market }\end{array}$ \\
\hline $\begin{array}{l}\text { Forker } \\
(1997)\end{array}$ & $\begin{array}{l}\text { TQM } \\
\text { implementation } \\
\text { together with } \\
\text { process } \\
\text { optimization }\end{array}$ & Rate of defectives & $\begin{array}{l}\text { Only TQM } \\
\text { implementation }\end{array}$ & Rate of defectives \\
\hline $\begin{array}{l}\text { Ittner and } \\
\text { Larcker } \\
\text { (1997) }\end{array}$ & $\begin{array}{l}\text { Long term } \\
\text { relationships with } \\
\text { suppliers and use } \\
\text { of process- } \\
\text { focused } \\
\text { improvement } \\
\text { tools }\end{array}$ & $\begin{array}{l}\text { Return on assets and } \\
\text { return on sales }\end{array}$ & $\begin{array}{l}\text { Training, quality } \\
\text { and team-based } \\
\text { reward systems and } \\
\text { organizational } \\
\text { commitment to } \\
\text { teamwork and } \\
\text { continuous } \\
\text { improvement }\end{array}$ & $\begin{array}{l}\text { Return on assets and } \\
\text { return on sales }\end{array}$ \\
\hline $\begin{array}{l}\text { Powell } \\
(1995)\end{array}$ & $\begin{array}{l}\text { Open culture, } \\
\text { employee } \\
\text { empowerment and } \\
\text { executive } \\
\text { commitment }\end{array}$ & Competitive advantage & $\begin{array}{l}\text { Quality training, } \\
\text { process } \\
\text { improvement and } \\
\text { benchmarking }\end{array}$ & Competitive advantage \\
\hline
\end{tabular}

Table 1. Studies on TQM and company performance. 


\begin{tabular}{|l|l|}
\hline TQM dimensions & Description \\
\hline $\begin{array}{l}\text { Employee relations } \\
\text { (ER) }\end{array}$ & $\begin{array}{l}\text { The primary responsibility for leading the drive to improve quality is that of } \\
\text { senior management. The incentives should be based on groups rather than } \\
\text { individuals and has to give more weight to quality. Other issues include the } \\
\text { importance given to training and the use of improvement teams and suggestion } \\
\text { schemes. }\end{array}$ \\
\hline $\begin{array}{l}\text { Organization } \\
\text { (O) }\end{array}$ & $\begin{array}{l}\text { Existence of a high level of cleanliness and organization of tools, fixtures and } \\
\text { the workplace. The position of the quality department in the organization has to } \\
\text { demonstrate independence. Application of quality management system } \\
\text { standards and the implementation of Total Productive Maintenance (TPM). }\end{array}$ \\
\hline $\begin{array}{l}\text { Product design process } \\
\text { (PDP) }\end{array}$ & $\begin{array}{l}\text { A well developed and understood new product development and design } \\
\text { (NPDD) process and effective co-ordination amongst the different departments } \\
\text { involved in NPDD have to be implemented. }\end{array}$ \\
\hline $\begin{array}{l}\text { Quality information } \\
\text { (QI) }\end{array}$ & $\begin{array}{l}\text { This includes a system of internal audits, measurement of the quality } \\
\text { management system, management review data and information availability. }\end{array}$ \\
\hline $\begin{array}{l}\text { Supplier relationship } \\
\text { (SR) }\end{array}$ & $\begin{array}{l}\text { Use of a small number of suppliers. Use of detailed requirements, which } \\
\text { suppliers have to follow as specified by the quality management system } \\
\text { standard. Participation of the supplier in the NPDD process. Supplier selection } \\
\text { according to quality criterion. }\end{array}$ \\
\hline $\begin{array}{l}\text { Process instruments } \\
\text { (PI) }\end{array}$ & $\begin{array}{l}\text { Use of appropriate statistical and non-statistical tools in the continuous } \\
\text { improvement process. }\end{array}$ \\
\hline $\begin{array}{l}\text { Design instruments } \\
\text { (DI). }\end{array}$ & $\begin{array}{l}\text { Use of appropriate tools and techniques in the process of designing a new } \\
\text { product and/or a new process. }\end{array}$ \\
\hline
\end{tabular}

Table 2. Seven TQM dimensions 


\begin{tabular}{|c|c|c|c|}
\hline \multirow[t]{11}{*}{ ADVERTISING: } & \multirow[t]{6}{*}{ Market rational behavior: } & - In favour: & Nelson $(1970,1974)$. \\
\hline & & - In certain cases: & Hertzendorf (1993) \\
\hline & & & Kihlstrom and Riordan (1984) \\
\hline & & & Milgrom and Roberts (1986) \\
\hline & & & Mizuno and Odagiri (1990). \\
\hline & & - Against: & Schmalensee (1978). \\
\hline & \multirow[t]{5}{*}{ Empirical research: } & - In certain cases: & Gotlieb and Sarel (1992) \\
\hline & & & Kirmani and Wright (1989) \\
\hline & & & Phillips et al. (1983) \\
\hline & & & Tellis and Fornell (1988) \\
\hline & & & Zeithaml (1988). \\
\hline \multirow[t]{19}{*}{ PRICE: } & \multirow[t]{6}{*}{ Market rational behavior: } & - In favour: & Allen (1984) \\
\hline & & & Balachander and Srinivasan (1994) \\
\hline & & & Gabor and Granger (1966) \\
\hline & & & Milgrom and Roberts (1986) \\
\hline & & & Wolinsky (1983). \\
\hline & & - In certain cases: & Cooper and Ross (1984). \\
\hline & \multirow[t]{13}{*}{ Empirical research: } & - In favour: & Dodds et al. (1991) \\
\hline & & & Gotlieb and Sarel (1992) \\
\hline & & & McConnell (1968) \\
\hline & & & Rao and Monroe (1989) \\
\hline & & & Stafford and Enis (1969) \\
\hline & & & Wheatley and Chiu (1977). \\
\hline & & - In certain cases: & Lambert (1980) \\
\hline & & & Lichtenstein and Burton (1989) \\
\hline & & & Pechmann and Ratneshwar (1992) \\
\hline & & & Zeithaml (1988). \\
\hline & & - Against: & Gardner (1971) \\
\hline & & & Sjolander (1992) \\
\hline & & & White and Cundiff (1978). \\
\hline \multirow[t]{5}{*}{ WARRANTIES: } & \multirow[t]{4}{*}{ Market rational behavior: } & - Against: & Cooper and Ross (1985) \\
\hline & & & Gal-Or (1989) \\
\hline & & & Lutz (1989) \\
\hline & & & Spence (1977). \\
\hline & Empirical research: & - In certain cases: & Boulding and Kirmani (1993). \\
\hline
\end{tabular}

Table 3. Impact of the extrinsic attributes on perceptions of quality 


\begin{tabular}{|l|c|}
\hline Nationality & Percentage \\
\hline Spanish & $54.7 \%$ \\
EU (European Union states), other than Spain & $27.8 \%$ \\
Europe, other than those belonging to the EU & $2.7 \%$ \\
United States & $9.9 \%$ \\
Japan & $3.6 \%$ \\
Others (Kuwait, Sweden and Australia) & $1.3 \%$ \\
\hline
\end{tabular}

Table 4. Nationality of the most important shareholders

\begin{tabular}{|l|c|l|}
\hline Dimension & Alpha & Suppressed items \\
\hline Employee Relations & 0.67 & Management have the main responsibility for quality \\
Organisation & 0.75 & None \\
Product Design Process & 0.76 & None \\
Quality Information & 0.76 & None \\
Supplier Relationship & 0.57 & None \\
Process Instruments & 0.88 & 100\% inspection sampling tables \\
Design Instruments & 0.85 & None \\
\hline
\end{tabular}

Table 5. Cronbach's alpha calculated for each dimension

\begin{tabular}{|l|c|c|}
\hline Variable & Mean & Standard Deviation \\
\hline Employee Relations & 3.08 & 0.76 \\
Organisation & 3.67 & 0.63 \\
Product Design Process & 3.72 & 0.69 \\
Quality Information & 3.56 & 0.77 \\
Process Instruments & 2.05 & 1.19 \\
Design Instruments & 1.19 & 1.3 \\
\hline
\end{tabular}

Table 6. Statistics of TQM dimensions. 


\begin{tabular}{|l|c|c|c|c|}
\hline Variable & Min & Max & Mean & Standard Deviation \\
\hline Market share growth & 1 & 5 & 3.85 & .97 \\
Unit costs & 1 & 4 & 2.88 & .73 \\
Operational profits & 1 & 5 & 3.29 & .92 \\
Advertising & 1 & 5 & 2.75 & 1.02 \\
Price & 1 & 5 & 3.20 & .70 \\
Warranties & 2 & 5 & 3.54 & .74 \\
\hline
\end{tabular}

Table 7. Summary statistics.

\begin{tabular}{|l|c|c|c|}
\hline $\mathbf{N}=\mathbf{2 2 3}$ & $\mathbf{1}$ & $\mathbf{2}$ & $\mathbf{3}$ \\
\hline Price & 1.00 & & \\
Advertising & $0.202(0.000)$ & 1.00 & 1.00 \\
Warranties & $0.226(0.000)$ & $0.189(0.000)$ & $0.031(0.526)$ \\
Employee Relations & $-0.027(0.585)$ & $0.011(0.838)$ & $0.091(0.071)$ \\
Organisation & $0.093(0.046)$ & $0.063(0.250)$ & $0.139(0.011)$ \\
Product Design Process & $0.093(0.076)$ & $0.071(0.251)$ & $-0.006(0.910)$ \\
Quality Information & $0.022(0.665)$ & $-0.026(0.642)$ & $0.027(0.606)$ \\
Process Instruments & $-0.059(0.180)$ & $0.058(0.269)$ & $0.057(0.255)$ \\
Design Instruments & $-0.050(0.297)$ & $0.029(0.545)$ & 0.057 \\
\hline
\end{tabular}

Table 8. Kendall's tau-c relating price, advertising, warranties and TQM dimensions. (Level of significance shown in brackets).

\begin{tabular}{|lcccc|}
\hline $\mathbf{N}=223$ & Price & Advertising & Warranties & Unit costs \\
\hline Market share growth & -0.051 & 0.141 & 0.070 & -0.095 \\
& $(0.317)$ & $(0.005)$ & $(0.191)$ & $(0.077)$ \\
\hline
\end{tabular}

Table 9. Kendall's tau-c relating price, advertising, warranties and production costs per unit in relation to competitors with market share growth. (Level of significance shown in brackets).

\begin{tabular}{|l|c|c|}
\hline $\mathbf{N}=223$ & Market share growth & Unit costs \\
\hline Employee Relations & $0.112(0.034)$ & $-0.140(0.012)$ \\
Organisation & $0.091(0.074)$ & $-0.058(0.246)$ \\
Product Design Process & $0.092(0.100)$ & $0.004(0.946)$ \\
Quality Information & $0.084(0.132)$ & $0.045(0.424)$ \\
Process Instruments & $0.084(0.090)$ & $-0.017(0.759)$ \\
Design Instruments & $0.126(0.007)$ & $-0.026(0.628)$ \\
\hline
\end{tabular}

Table 10. Kendall's tau-c relating market share growth and unit costs of production with TQM dimensions.

(Level of significance shown in brackets). 


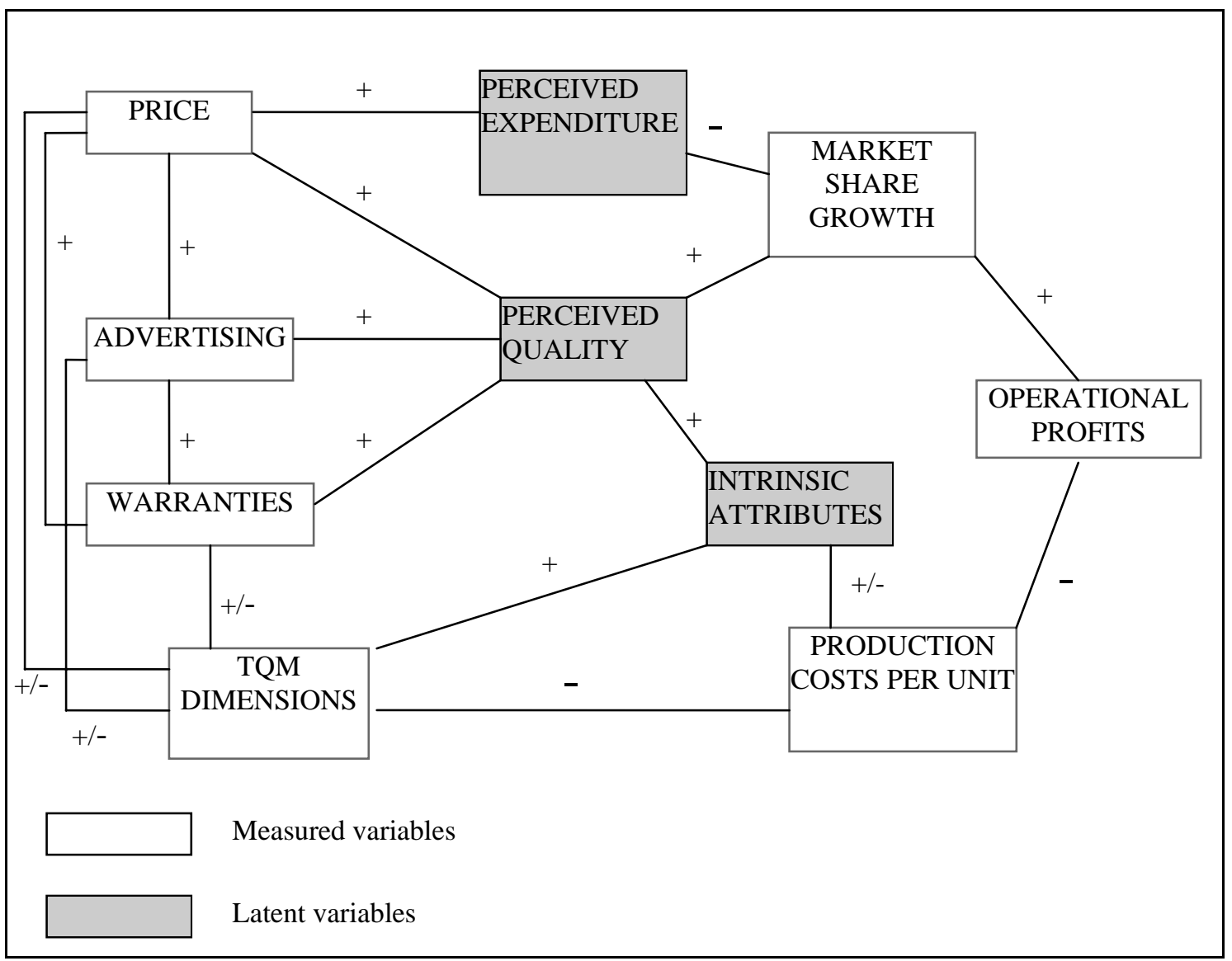

Fig. 1. Proposed model of the relationships amongst marketing variables, TQM and performance. The + symbol indicates a positive relationship, the - symbol a negative relationship and the $+/$ - symbol a non-specific relationship. 


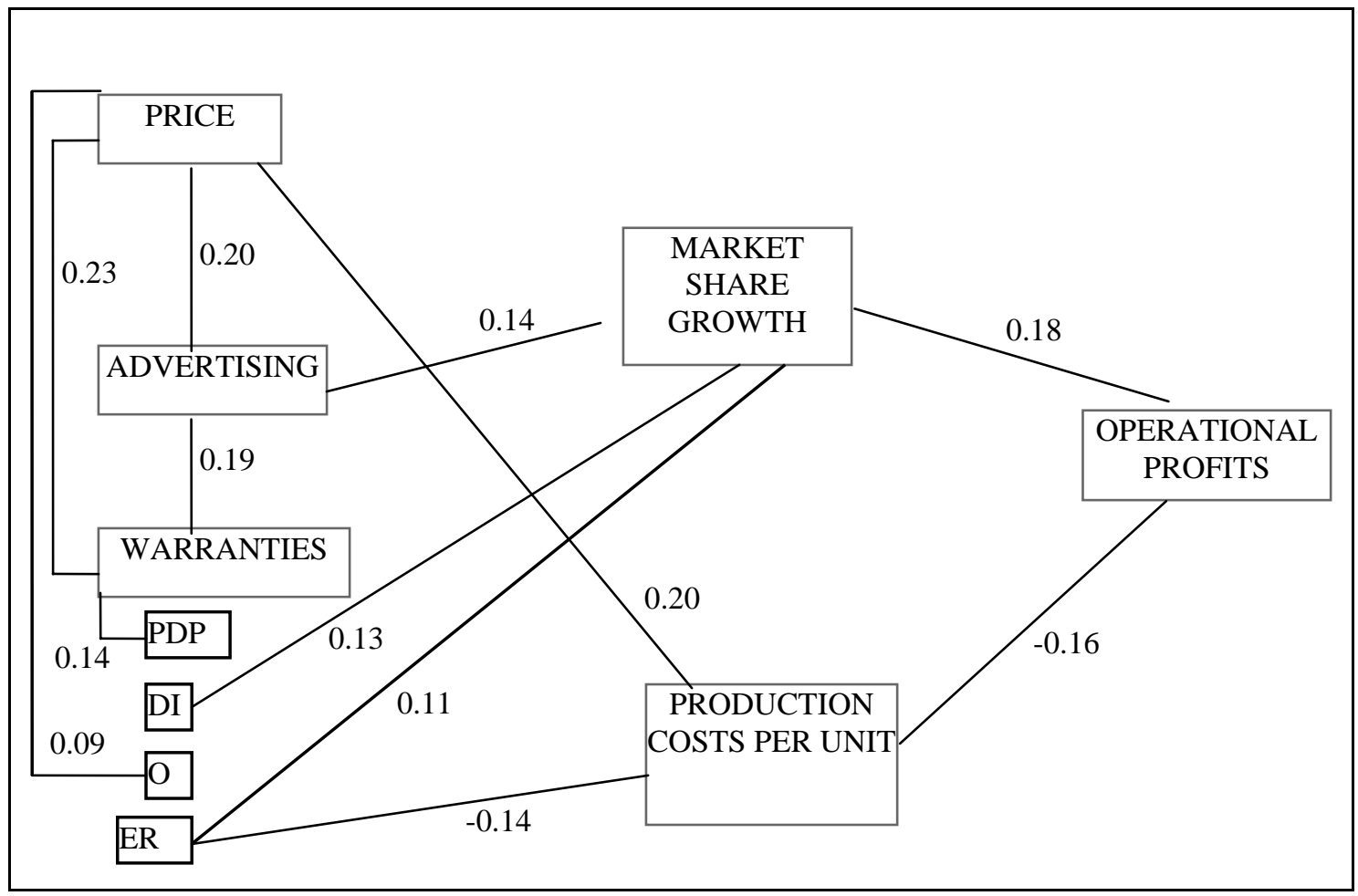

Fig. 2. Revised model of the relationships amongst marketing variables, TQM and Performance. (The numbers are Kendall's tau-c values). 


\section{APPENDIX}

The questionnaire was written in Spanish. The English translation is only provided to assist the reader and has not been verified.

\section{Employee relations (ER).}

1. La obtención de la adecuada calidad depende en primer lugar del directivo.

2. Su sistema de incentivos prima la calidad más que otros factores.

3. En su empresa tienen preferencia los incentivos grupales sobre los individuales.

4. La formación impartida a los trabajadores de planta por parte de la empresa es intensa.

5. El nivel de utilización del trabajo de círculos de calidad u otros sistemas de trabajo en grupo en su empresa es muy alto. 6. La importancia y tratamiento concedido a las sugerencias de los trabajadores de planta es muy alta.

\section{Organisation (0).}

1. El nivel de limpieza y organización de las herramientas que tienen en la planta es muy alto.

2. La importancia de su departamento de calidad dentro de la estructura de su empresa en cuanto a la influencia sobre las decisiones es muy alta.

3. El nivel de utilización del manual de calidad/procedimientos es muy alto.

4. El nivel de aplicación de los postulados de alguna Norma oficial de calidad es muy alto. 5 . El grado en que realizan en su empresa actividades de "Mantenimiento Productivo Total" es muy alto.

\section{Product design process (PDP).}

1. El grado en que se planifican las actividades encaminadas a mejorar la calidad del producto es muy alto.

2. La meticulosidad en las revisiones del diseño de un nuevo producto antes de ser producido y vendido es muy alta.

3. El grado de coordinación entre los departamentos afectados en el proceso de desarrollo del producto es muy alto.
1. Management have the main responsibility for quality.

2. The incentive system gives more weight to quality than others factors.

3. Incentives for groups have preference over individual incentives in your company.

4. Training given to workers by the company is intense.

5. The use of quality circles or other systems of teamwork is very high.

6. Importance and consideration which is given to workers' suggestions is considerable.

1. The level of cleanliness and organization of shop floor tools is very high.

2. The position of the quality department in the organizational structure gives it the appropriate importance in the decision process.

3. Considerable use is made of quality procedures.

4. The level of application of quality management systems is very high.

5. Considerable use is made of "Total Productive Maintenance" activities.

1. Activities to improve product quality are planned.

2. The product design is meticulously reviewed before it is produced and sold.

3. The co-ordination among the departments involved in the product development process is very high. 
Quality information (QI).

1. La frecuencia con que realizan auditorías internas de la calidad es muy alta.

2. El nivel en que miden el resultado de su sistema de gestión de la calidad es muy alto. 3 . El grado en que los resultados de su sistema de gestión de la calidad están disponibles para cualquier persona de su empresa que los desee es muy alto.

\section{Supplier relationship (SR).}

1. Trabajan con un número razonablemente reducido de proveedores de confianza.

2. El que su proveedor esté certificado según una norma oficial de calidad es muy importante para su empresa.

3. Se involucra a los proveedores en el proceso de desarrollo del producto.

4. El grado en el cual sus proveedores son seleccionados en base a su calidad más que en base a otros factores es muy alto.

\section{Quality tools usage in the process (PI).}

1. Inspección al $100 \%$.

2. Inspección estadística de recepción (muestreo de aceptación).

3. Control estadístico del proceso.

4. Estudios estadísticos de capacidad.

5. Diagrama causa efecto o de espina de pescado o de Ishikawa.

6. Análisis de Pareto o diagrama ABC.

7. Histogramas.

8. Diagramas de dispersión correlación.

9. Brainstorming.

10. Q.Q.D.C.C.P.C. (responder para un problema a las preguntas que? quien? donde? cuando? como? por que? cuanto?)

11. Matriz de compatibilidad.
1. There is a planned program of internal quality audits.

2 . The result of your quality management system is measured.

3. The results of your quality management systems are made available to every employee.

1. Your company works with a reasonably small number of suppliers.

2. The fulfillment of a quality official Norm by the supplier is considered important for your company.

3. The suppliers are involved in the product development process.

4. Your suppliers are chosen by their quality performance more than by others factors.

1. $100 \%$ inspection.

2. Sampling tables.

3. Statistical process control.

4. Capability indices.

5. Ishikawa diagram.

6. Pareto diagram.

7. Histograms.

8. Correlation.

9. Brainstorming.

10. What, Who, Where, When, How, Why, How much?

11. Compatibility matrix. 
Quality tools usage in the design (DI). 1. Métodos de Taguchi.

2. Análisis modal de fallos y efectos (AMFE).

3. Casa de la calidad (Quality Function Deployment, QFD).

4. Análisis del valor.

\section{Business performance variables}

Durante los últimos 5 años su cuota de mercado:

a) Ha disminuido considerablemente.

b) Ha disminuido algo.

c) Se ha mantenido.

d) Ha aumentado algo.

e) Ha aumentado considerablemente.

Con respecto a las empresas que compiten con su producto, (1. muy inferior, 2. algo inferior, 3. similar, 4. algo superior, 5. muy superior)

1. su coste unitario de produccion medio de los últimos 5 años ha sido:

2. su cifra media de beneficios antes de intereses e impuestos sobre ventas de los últimos 5 años ha sido:

\section{Marketing variables}

Con respecto a las empresas que compiten con su producto, (1. muy inferior, 2. algo inferior, 3. similar, 4. algo superior, 5. muy superior)

1. el gasto en publicidad de su producto es, en promedio:

2. el precio de su producto es, en promedio:

3. las garantias ofrecidas son, en promedio:
1. Taguchi methods.

2. Failure Mode and Effects Analysis (FMEA)

3. Quality Function Deployment (QFD).

4. Value analysis.

During the past 5 years, your market share:

a) Has reduced significantly.

b) Has reduced by a small amount.

c) Has remained the same.

d) Has increased by small amount.

e) Has increased significantly.

Compared with the companies that compete with your product, (1. far superior than average, 2. higher than average, 3 . average, 4. below average, 5 . far below average)

1. your average production cost per unit of the last 5 years has been:

2. your earnings before interest and tax over sales during the past 5 years have been:

Compared with the companies that compete with your product, (1. far superior than average, 2. higher than average, 3 . average, 4. below average, 5 . far below average) 1. the advertising expenditures in your product are, on average:

2. the price of your product is, on average:

3. the warranties offered are, on average: 